\title{
The Effects of Seductive Details and Concrete Elaboration of English Texts on Comprehension and Interest of 2nd Year EFL High School Students
}

(Ph. D. Candidate, State University of New York at Buffalo)

\begin{abstract}
Two major purposes motivated and guided the present study: to examine the effects of seductive details and concrete elaboration on 2nd year high school students' written text comprehension and interest, and to determine whether seductive details and concrete elaboration can serve as the basis for effective textbook design and comprehension instruction. Major findings include: (a) seductive details were detrimental to the main idea comprehension of intermediate proficiency students, (b) concrete elaboration enhanced main idea comprehension of high proficiency students, whereas it significantly interfered with main idea comprehension of intermediate proficiency students, and (c) seductive details and concrete elaboration did not enhance reader' perceived interest of modified versions they read. The findings have implications for both English textbook designers and practitioners.
\end{abstract}

Key Words : seductive details, concrete elaboration, comprehension, interest

\section{I . Problem Statement}

Making textbooks interesting and comprehensible is important not only because textbooks are an essential part of classroom instruction and learning, but also because interesting materials engage 
readers in "deeper cognitive processing" (Tobias, 1994, p. 37). However, textbooks have often been criticized because many students find the textbooks uninteresting and poorly written (Harp \& Mayer, 1997). For instance, Sadoski (2001) accused textbooks of "being either lifeless and insipid or dazzling and provocative at the expense of responsible accuracy in delivering their content" (p. 264).

In response to this mounting criticism, L1 researchers have made efforts to make textbooks more interesting, comprehensible, and memorable (Sadoski, Goetz, \& Rodriguez, 2000). Specifically, they have attempted to address this issue through the following approaches: (a) including suspense and unexpected information (Hidi, 1990), (b) increasing coherence (Beck, McKeown, \& Worthy, 1995), (c) including illustrations or concrete language (Sadoski, 2001), and (d) adding seductive details (Garner, Gillingham, \& White, 1989).

In contrast, L2 text modification researchers (Oh, 2001; Yano, Long, \& Ross, 1994) rarely considered the role of the affective variable of reader interest aroused by text characteristics. In other words, there is little guidance from L2 researchers with regard to constructing interesting and comprehensible textbooks. Interesting and comprehensible textbooks are of great importance for EFL readers because interesting and comprehensible textbooks have the potential to stimulate EFL readers to engage in extensive reading, a task which is indispensable for learning and language development (Elley, 1991; Krashen, 1985).

Accordingly, the present study explores the effects of seductive details (Garner, Gillingham, \& White, 1989) and concrete elaboration, (Sadoski, 2001) which are said to evoke readers' text-based situational interest and which are rarely investigated in the L2 contexts.

Seductive details are defined as highly entertaining and personally appealing information that only has a tangential relationship to the important ideas of the text (Garner, Gillingham, \& White, 1989). The underlying premise of seductive details is that when seductive details are added in a text, they will enhance reader interest, attention, and learning. That is, if seductive details grasp the readers' interest, readers will pay more attention to the important ideas, therefore ultimately increasing their comprehension.

In combination with the examination of seductive detail effects, the present study also examines the effects of concrete elaboration. As mentioned previously, concrete elaboration also evokes the text-based interest of readers, much like seductive details (Schraw \& Lehman, 2001). Concrete elaboration refers to replacing less concrete words with more concrete counterparts, while maintaining the coherence and meaning of the passage (Sadoski, Goetz, \& Rodriguez, 2000). The basic premise of concrete elaboration is that concrete language evokes imagery, which in turn 
generates interest and affective engagement, makes the materials "come to life" (Sadoski, Goetz, and Rodriguez, 2000, p. 87), and eventually facilitates reader comprehension and recall (Sadoski, 2001).

Taking such information into consideration, the major purpose of this study is to examine the effects of two comprehension- and interest-evoking approaches (seductive details and concrete elaboration) on the reading comprehension and interest of EFL high school students who have different levels of English language proficiency (intermediate and high). The following research questions guided the present study:

1. What are the effects of text types (seductive details and concrete elaboration) on written text comprehension of Korean high school students who have different English language proficiency levels (high and intermediate)?

2. What interaction effects can be seen between text types and language proficiency levels?

3. What are the effects of text type and proficiency on the self-ratings of comprehensibility and interestingness?

\section{II . Review of Literature}

\section{Research on Seductive Details}

While several L1 researchers documented the detrimental effects of seductive details on reader comprehension (Garner, Gilligham, \& White, 1989; Harp \& Mayer, 1998), the research findings are inconsistent (e.g., Schraw, 1998).

Garner, Gilligham, and White (1989) were among the first L1 researchers who examined the effects of seductive details. Garner et al. found there were detrimental effects of seductive details on a reader's ability to recall main ideas in one of the two experiments the researchers conducted. Data analysis indicated that the participants in the seductive detail condition recalled significantly fewer main ideas. Similar results were found by Wade, Schraw, Buxton, and Hayes' (1993) study. Wade et al. found that significantly more seductive details were recalled than main ideas were.

Unlike previous studies that did not include a seductive detail control group (Garner, Alexander, 
Gillingham, Kulikowich, \& Brown, 1991; Wade, Schraw, Buxton, \& Hayes, 1993), two studies by Harp and Mayer (1997, 1998) did include control group. The results from those two studies indicated detrimental effects of seductive details. Post hoc analysis revealed that the participants who read base text only remembered more idea units than did the other three groups containing both seductive texts and seductive illustrations. The second study by Harp and Mayer (1998) replicated the findings of their previous study (Harp \& Mayer, 1997).

However, Schraw's (1998) study did not document seductive details effects. His study showed that seductive details had small positive effects on gist recall. In a related vein, Schraw, Lehman, and Hartley's (2002) research did not show negative effects of seductive details when seductive details were coherently integrated in the text.

In contrast to L1 researchers, L2 researchers rarely focused on the effects of seductive details. Only Song (2003), in his doctoral dissertation, examined the effects of seductive details. He found that seductive details were detrimental to the main and specific idea recall of $118 \mathrm{EFL}$ undergraduate students.

\section{Research on Concrete Elaboration}

Research findings on the effects of concrete elaboration have consistently shown positive effects of concrete elaboration on reader comprehension. However, there are a limited number of research studies that directly examine the effects of concrete elaboration on reader comprehension and interest (Beck, McKeown, \& Worthy, 1995; Hidi \& Baird, 1988; Sadoski, Goetz, \& Fritz, 1993; Sadoski, Goetz, \& Rodriguez, 2000). Moreover, none of these studies were conducted in the L2 contexts.

Sadoski and his colleagues conducted a series of concrete elaboration studies. The findings from these three studies consistently supported concrete elaboration. As in previous findings (Sadoski, Goetz, Fritz, 1993), Sadoski, Goetz, and Avila (1995) also found significant concrete elaboration effects in the two experiments they conducted.

A recent study by Sadoski, Goetz, and Rodriguez (2000) replicated earlier studies of Sadoski and his colleagues (1993, 1995). The analysis of correlation between the ratings of familiarity, concreteness, interestingness, and comprehensibility indicated high positive correlations. The ratings of comprehensibility and concreteness had very high correlation $(r=.96)$, findings that were consistent with the previous study (Sadoski, Goetz, \& Fritz, 1993). Interestingness and comprehensibility also had a high positive correlation, $r=.85$. Although the three studies by 
Sadoski and his colleagues $(1993,1995,2000)$ showed significant effects of concrete elaboration on reader comprehension and comprehensibility ratings, they did not report effect size in many cases. Thus, it is difficult to assess how practically significant the differences were.

In sum, the present literature review indicates that (a) research findings on seductive details are mixed, and that (b) research findings on concrete elaborations consistently show positive effects on reader comprehension. The present literature review also clearly indicates that we know little about the degree to which seductive details and concrete elaboration may influence the reading comprehension and interest of EFL readers.

\section{METHOD}

This quantitative study is designed to investigate the effects of seductive details and concrete elaboration (a) on the reading comprehension of EFL high school students, and (b) on the self-ratings of comprehensibility, interestingness, and concreteness. Quantitative methods were used in this study because they are appropriate since the purpose of the study is to identify factors that may impact a particular outcome and thus test aspects of a specific theory as Creswell (2003) noted. Indeed, the present study focuses on identifying how the factors of seductive details and concrete elaboration influence the outcome of EFL readers' comprehension.

\section{Participants}

156 second year Korean high school students participated in the present study. They were recruited from seven classrooms in a local high school. Participation in the present study was contingent upon the approval from the school principal, and also upon the consent from the students and their parents. The participants represent high school students who attend regular, not vocational or specialized, schools.

Based on the English Language test scores of the preparatory College Scholastic Ability Test administered March 2006, the participants were classified into high, intermediate, and low levels. Mean English Language test scores for high and intermediate proficiency groups were 81.57 and 57.56, respectively, while the school and the national mean scores were 58.30 and 46.00, respectively. High and intermediate level students were then randomly assigned to an experimental condition: base, seductive detail, or concrete elaboration. This resulted in six groups: High-Base 
(HB), High-Seductive (HS), High-Concrete (HC), Intermediate-Base (IB), Intermediate-Seductive (IS), Intermediate-Concrete (IC). Each group included 26 participants.

\section{Materials}

The materials used in this study consisted of (a) reading passages, (b) comprehension questions, and (c) a questionnaire inquiring about demographic information and another questionnaire soliciting the subjects' background knowledge about the texts and the two self-ratings of comprehensibility and interestingness. Although subjective in nature, the validity of the materials were examined and validated by an American professor who is an expert in ESL/EFL education in the United States.

\section{(1) Reading Passages}

Based on four base texts, four seductive details and four concrete elaboration versions were constructed. More specifically, partially following Sadoski, Goetz, and Fritz (1993), four base texts were selected, each including a historical figure from different disciplines. The texts were obtained from several sources and with permission to reprint the materials from the publishers: (a) Cracking the SSAT \& ISEE 2006 Edition, (b) Barron's Let's Prepare for the Grade 8 Language Arts Test, and Spectrum New York Test Prep Grade 5. Four important experimental controls were placed on the selection of base texts and the construction of seductive details and concrete elaboration versions:(a) text interestingness, (b) prior knowledge, (c) coherence and (d) readability.

First, text interestingness was controlled since, as Schraw and Lehman (2001) posited, inconsistent findings in seductive details research may potentially have been due to the reason that seductive may be less detrimental in an already intriguing text. Second, to control for the confounding variable of prior knowledge in reading comprehension (Johnston, 1984), the researcher made sure that Korean high school students were not familiar with the historical figures appearing in the texts through prior knowledge questionnaire as well as through pilot studies.

Third, research showed that text coherence is an important factor in text comprehension (Beck, McKeown, \& Worthy, 1995). Schraw, Lehman, and Hartley's (2002) research indicated that seductive details might be detrimental only when they are not coherently integrated into a text. Finally, readability level was approximately equated among base, seductive, and concrete versions using the Flesch-Kincaid Grade Level formula (Klare, 1984). 
〈TABLE 1〉 Text Lengths and Readability for Each Text

\begin{tabular}{c|c|c|c|c|c|c|c|c}
\hline \multirow{2}{*}{ Text } & \multicolumn{2}{|c|}{ Base } & \multicolumn{2}{c|}{ Seductive Details } & \multicolumn{2}{c|}{ Concrete Elaboration } & \multicolumn{2}{c}{ Mean } \\
\cline { 2 - 9 } & Words & Readability & Words & Readability & Words & Readability & Words & Readability \\
\hline A & 245 & 8.8 & 384 & 8.5 & 326 & 8.6 & 316.00 & 8.63 \\
B & 291 & 8.5 & 366 & 8.3 & 368 & 8.3 & 341.67 & 8.4 \\
C & 153 & 10 & 224 & 10 & 263 & 9.6 & 211.33 & 9.9 \\
D & 260 & 11.3 & 370 & 10.7 & 312 & 11.5 & 318.33 & 11.2 \\
Mean & 237.25 & 9.65 & 336 & 9.38 & 317.25 & 9.50 & 296.83 & 9.51 \\
\hline
\end{tabular}

\section{(2) Comprehension Questions}

In all, twelve comprehension questions (4 different texts $x 3$ questions $=12$ ) were prepared to measure the effects of seductive details and concrete elaboration on reader comprehension. The questions were based on common idea units across base, seductive, and concrete versions. That is, all the participants took the same comprehension test irrespective of the type of texts. For each text, the researcher chose one main and two other comprehension questions.

\section{(3) Questionnaire}

A third major instrument included questionnaires that examined the readers' background knowledge and self-ratings of interestingness and comprehensibility. To that end, the participants were instructed to respond to a scale from 1 to 5 (for more information, refer to Appendix 2).

\section{(4) Procedures}

The main study was conducted in high school classrooms with the assistance of classroom teachers. With permission, regular class hours were used. The participants were given the packet that corresponded to his or her condition by the classroom teachers. Each packet contained four texts which were randomly ordered. The packets were placed face down until the participants were instructed to provide their class number, gender, and age on the first questionnaire. Then, the participants were instructed to respond to the prior knowledge questionnaire. After finishing the questionnaire, the participants read the first text, and responded to the comprehension questions. Next, they were asked to respond to the first questionnaire which inquires about the participants' prior knowledge and self-ratings of comprehensibility and interestingness. For the participants to complete all the tasks, they were given 40 minutes. 


\section{IV . Results}

\section{Effects of Text Types and Proficiency on Comprehension}

Prior to the main data interpretation, the data were screened for outliers and normality of distribution. There were no obvious outliers, and both kurtosis and skewness tests indicated no serious departure from normality (all tests resulted in absolute values of less than .39). In addition, Levene's test of equality of error variances confirmed that the error variances of each of the dependent variables are equal across groups (all ps $>.05$ ).

\section{(1) Effects of Text Types on Reading Comprehension}

Regarding main idea comprehension, BT (base texts) students scored highest $(\mathrm{M}=2.96)$ followed by $\mathrm{CE}$ (concrete elaboration texts) students $(\mathrm{M}=2.73$ ) and SD (seductive details texts) students $(\mathrm{M}=2.58)$. A two-way ANOVA indicated a significant main effect for text types on comprehension of main ideas scores, $\mathrm{F}(2,153)=3.135, \mathrm{p}<.05, \mathrm{ES}=.04$.

Because the overall $\mathrm{F}$ test indicated a significant main effect for text types, post hoc pairwise comparisons were performed to determine where statistically significant pairwise differences existed among the three main effect means for different text types. Bonferonni post hoc tests, using the three group's mean score differences, revealed that BT students significantly outperformed SD students (mean difference $=.39$ ). In contrast, no other statistically significant mean difference was found between BT and CE students (mean difference $=.23$ ), and CE and SD students (mean difference $=.15)$.

In addition to main idea comprehension, the overall comprehension score was computed by summing the total number of correct responses from all four texts. Each correct response was given 1 point. The resulting scores ranged from 3 to 12 . BT students scored highest $(M=8.15)$, followed by $C E$ students $(M=8.12)$ and SD students $(M=7.62)$. The two-way ANOVA showed that mean differences between BT and SD (= .54), BT and CE (=.04), and CE and SD (= .50) were only marginally significant, $\mathrm{F}(2,153)=2.155, \mathrm{p}=.13$. 
〈TABLE 2〉 Descriptives from Main Idea and Overall Comprehension Test

\begin{tabular}{|c|c|c|c|c|c|}
\hline $\begin{array}{l}\text { Dependent } \\
\text { Variables }\end{array}$ & $\begin{array}{l}\text { Text } \\
\text { Types }\end{array}$ & Proficiency & Mean & $\begin{array}{l}\text { Standard } \\
\text { Deviation }\end{array}$ & $\mathrm{N}$ \\
\hline \multirow{9}{*}{$\begin{array}{c}\text { Main Idea } \\
\text { Comprehension }\end{array}$} & \multirow{3}{*}{ BT } & $\mathrm{H}$ & 3.19 & .57 & 26 \\
\hline & & I & 2.73 & .72 & 26 \\
\hline & & Total & 2.96 & .69 & 52 \\
\hline & \multirow{3}{*}{$\mathrm{SD}$} & $\mathrm{H}$ & 3.04 & .82 & 26 \\
\hline & & I & 2.12 & .86 & 26 \\
\hline & & Total & 2.58 & .96 & 52 \\
\hline & \multirow{3}{*}{$\mathrm{CE}$} & $\mathrm{H}$ & 3.38 & .80 & 26 \\
\hline & & I & 2.08 & .94 & 26 \\
\hline & & Total & 2.76 & 1.09 & 52 \\
\hline \multirow{9}{*}{$\begin{array}{c}\text { Overall } \\
\text { Comprehension }\end{array}$} & \multirow{3}{*}{ BT } & $\mathrm{H}$ & 9.15 & 1.16 & 26 \\
\hline & & I & 7.15 & 1.59 & 26 \\
\hline & & Total & 8.15 & 1.71 & 52 \\
\hline & \multirow{3}{*}{$\mathrm{SD}$} & $\mathrm{H}$ & 8.88 & 1.45 & 26 \\
\hline & & I & 6.35 & 1.62 & 26 \\
\hline & & Total & 7.62 & 1.99 & 52 \\
\hline & \multirow{3}{*}{$\mathrm{CE}$} & $\mathrm{H}$ & 9.73 & 1.46 & 26 \\
\hline & & I & 6.50 & 1.71 & 26 \\
\hline & & Total & 8.12 & 2.26 & 52 \\
\hline
\end{tabular}

$* \mathrm{BT}=$ base text, $\mathrm{SD}=$ seductive details, $\mathrm{CE}=$ concrete elaboration, $\mathrm{H}=$ high, $\mathrm{I}=$ intermediate

\section{(2) Effects of Proficiency on Reading Comprehension}

In contrast to the mixed findings in the effects of text types on reading comprehension, a two-way ANOVA indicated that HP (high proficiency) students significantly outperformed IP students (intermediate proficiency) in both main idea and overall comprehension. Specifically, for main idea comprehension, HP students ( $\mathrm{M}=3.21$ ) outperformed IP (intermediate proficiency) students $(\mathrm{M}=2.31)$ to a statistically significant degree, $\mathrm{F}(1,154)=116.836, \mathrm{p}<.001$. The effect size for this difference was large: $\mathrm{ES}=.440$.

Similar results were found for overall comprehension. HP students $(\mathrm{M}=9.26)$ outperformed IP students $(\mathrm{M}=6.67)$ to a significant degree, $\mathrm{F}(1,154)=49.98, \mathrm{p}<.001$ (mean difference $=2.59$ ). The effect size for this difference was also large: ES $=.440$.

\section{(3) Interaction Effects between Text Types and Proficiency on Comprehension}


The second research question is concerned with the interaction effects between text type and the level of learner proficiency on main idea and overall comprehension. As shown by Figure 1, a two-way ANOVA revealed that a significant interaction occurred for main idea comprehension only, $\mathrm{F}(2,153)=49.98, \mathrm{p}<.05, \mathrm{ES}=.047$. This interaction is due to the fact that while seductive details had very small detrimental effects on HP students $(M=3.04)$, seductive details significantly interfered with the main idea comprehension of IP students' $(M=2.12)$. Moreover, although concrete elaboration enhanced HP students' $(M=3.38)$ comprehension of main ideas, IP students $(\mathrm{M}=2.08)$ who read concrete elaboration passages significantly performed worse than IP students $(M=2.73)$ who read base texts.

On the other hand, regarding overall comprehension, no statistically significant interaction was observed, $\mathrm{F}(2,153)=29.203, \mathrm{p}=.114$, ES $=.029$. However, as shown by Figure 2, marginally significant interaction effect is worthy of future study.

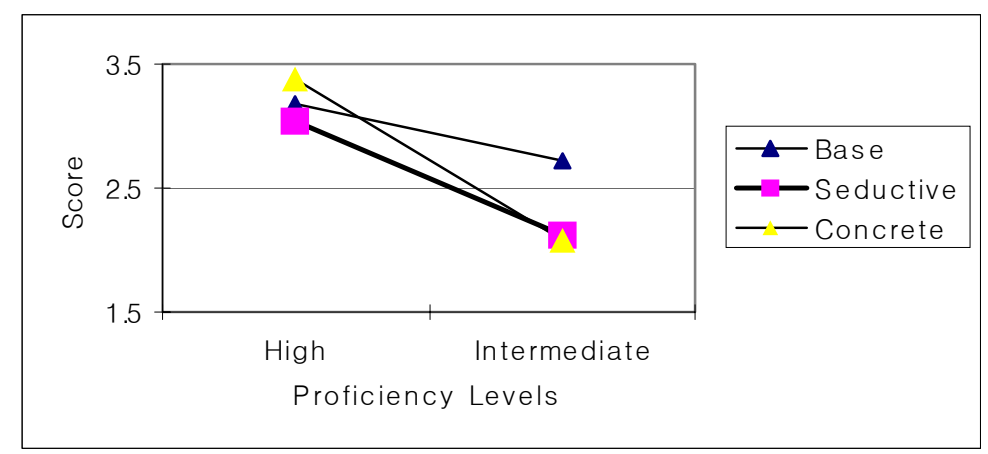

〔FIGURE 1) Means of Main Idea Comprehension Scores

\section{Effects of Text Types and Proficiency on Self-Ratings}

In order to ensure that self-ratings met the standards for reliability, the self-ratings were also assessed to make that determination. Overall, the Alpha reliability coefficient for the ratings was very high, $\mathrm{r}=.88$. In addition, self-ratings were screened for outliers and normality of distribution before the main data was analyzed. No obvious outliers were observed. Moreover, both kurtosis and skewness tests indicated no serious departure from normality. Levene's test of equality of error variance indicated that the error variance of the ratings was equal across groups (all ps > .05).

Multiple analysis of variance (MANOVA) was run to determine the effects of text types and 
proficiency levels on the self-ratings of comprehensibility and interestingness as dependent variables. 2 x 3 MANOVA indicated no significant main effects for text type. In contrast, there were significant main effects of proficiency levels on each of self-ratings. Yet no interaction effects between text types and self-ratings were found.

\section{(1) Effects of Text Type on Self-Ratings}

Regardless of the types of self-ratings, SD students consistently provided the highest comprehensibility and interestingness ratings $(M=13.62,13.25)$. BT students gave the second highest ratings $(M=13.15,12.87)$, while $C E$ students provided the lowest ratings $(M=12.77$, 12.04). However, the mean differences among the groups were not significant. Consistent with the results of MANOVA, additional ANOVAs on each self-rating as dependent variables also indicated that there were no significant main effects for text types on all self-ratings: comprehensibility rating, $\mathrm{F}(2,153)=1.002, \mathrm{p}=.370$ and interestingness rating, $\mathrm{F}(2,153)=$ $2.432, \mathrm{p}=.091$.

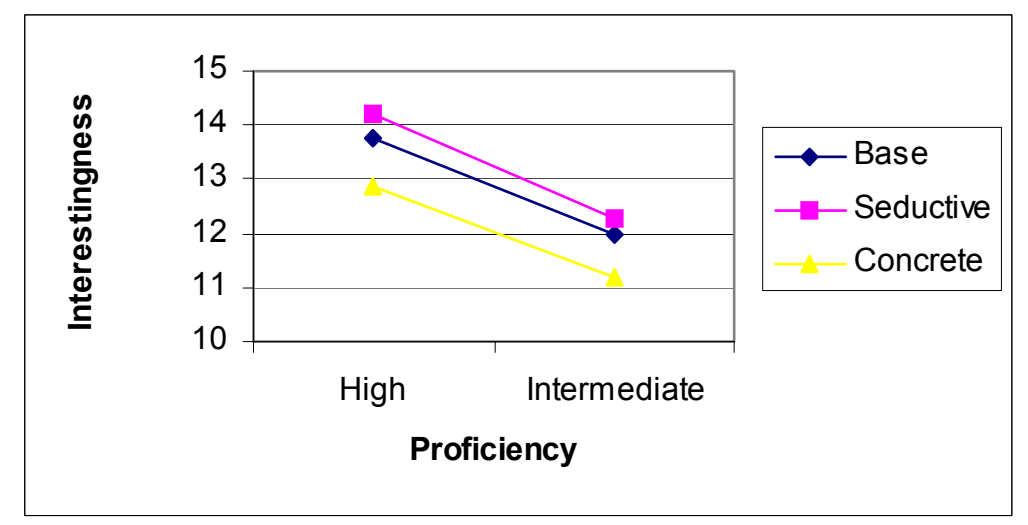

〔FIGURE 2〕 Means of Interestingness Rating

\section{(2) Effects of Proficiency on Self-Ratings}

For both comprehensibility and interestingness, HP students provided significantly higher ratings than IP students. More specifically, for comprehensibility rating, the mean difference $(=4.493)$ between HP ( $(M=15.526)$ and IP students $(M=11.01)$ was significant, $F(1,154)=91.933$, $p<$ .001 , ES $=.382$. The mean comprehensibility ratings indicated that HP students responded that they understood the passages they read approximately $80 \%$, whereas IP students responded that 
they understood the passages less than $60 \%$.

Interestingness ratings were also significant between HP $(M=13.63)$ and IP students $(M=$ 11.81 ), with a mean difference of $1.936, \mathrm{~F}(1,154)=18.085, \mathrm{p}<.001$, ES $=.108$. The mean interestingness ratings indicate that HP students generally considered the reading passages as less than interesting. On the other hand, IP students rated the passages as less than neutral (neither interesting nor uninteresting).

\section{(3) Interaction Effects between Text Type and Proficiency on Self-Ratings}

Regarding interaction effects between text types and proficiency, ANOVA revealed no statistically significant interaction on all types of ratings for comprehensibility and interestingness: for comprehensibility, $\mathrm{F}(2,153)=.070, \mathrm{p}=.933$ and for interestingness, $\mathrm{F}(2,153)=.028, \mathrm{p}=$ .972. In other words, HP students consistently provided more significant comprehensibility and interestingness ratings than IP students no matter what type of texts the students read.

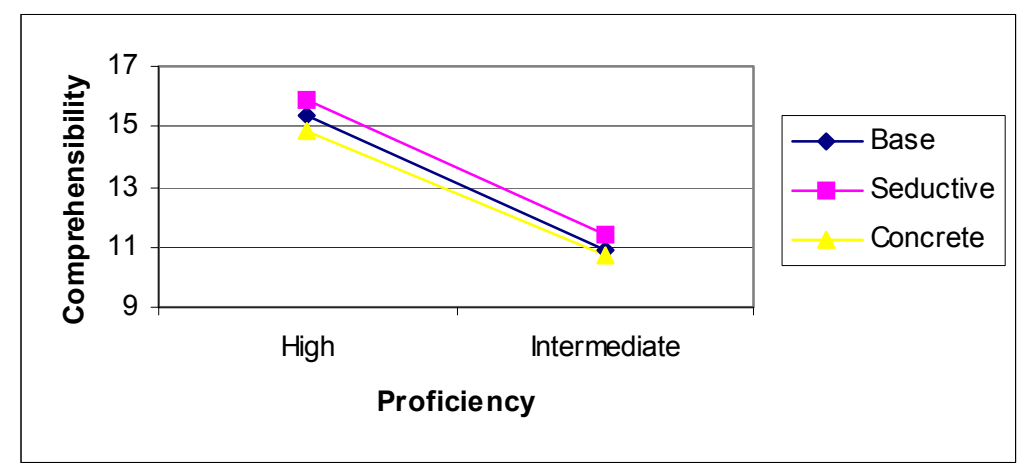

[FIGURE 3) Means of Comprehensibilty Rating

\section{Discussions}

The researcher analyzed the responses of 2 nd year high school students to a set of four expository texts to address three important issues in reading comprehension and text-based reader interest research. The following section is devoted to discussing the issues the researcher proposed. 


\section{Effects of Seductive Details and Concrete Elaboration on L2 Reading}

\section{Comprehension}

Concerning question 1 , the results of the present study revealed that seductive details were detrimental to varying degrees. For instance, seductive details were significantly detrimental on main idea comprehension, whereas they did not significantly interfere with overall comprehension. The results also revealed that concrete elaboration did not necessarily facilitate student comprehension. With regard to question 2, significant interaction was observed. For instance, proficient readers were less seduced by seductive details. They were more able to distinguish important ideas from interesting and less important details than less proficient readers.

\section{(1) Effect of Seductive Details}

For main idea comprehension, the results of the study showed that students who read the seductive detail passages performed significantly worse than those who read base passages. This finding is consistent with Harp and Mayer (1997) and extends the findings of Harp and Mayer in terms of research methodology. In Harp and Mayer's study, the researchers used recall method to assess reader comprehension, while the present study used multiple choice tests. Both measures identified detrimental effects of seductive details.

As an additional extension to the findings of Harp and Mayer (1997, 1998), the results of this study reveal that there were significant interaction effects. Seductive details were significantly detrimental to IP students, whereas HP students were rarely distracted by seductive details. IP students who read texts containing seductive details scored significantly lower on main idea comprehension than those at the same proficiency level who read base texts. On the other hand, HP students who read either seductive details or base passages did not differ significantly. This finding shows that seductive details are not equally detrimental to all levels of language proficiency.

Possibly, different seductive detail effects on IP and HP students could have resulted from the lack or presence of metacognitive awareness among readers of different proficiency. Unlike IP students, HP students might have already developed metacognitive awareness in reading comprehension, which is the ability to regulate one's thinking and the strategies one is using (Baker \& Brown, 1991). That is, HP students may have monitored their comprehension, 
consciously applied one or more strategies to correct their comprehension, and actively distinguished important ideas from interesting details by selectively allocating their attention. Therefore, they might have been less distracted by seductive details. However, this may not have been the case with IP students. Research findings provide support for this interpretation. For instance, Paris and Meyers (1981) documented that less proficient readers did not engage in active monitoring as often as proficient readers did.

It is also possible that the significantly poor performance of IP students can be attributed to both lack of fluent word recognition skills (Samuels, 2004) and longer passages. Some IP students may not have developed fluent word recognition skills (Segalowitz, Segalowitz, \& Wood, 2003). Their poor word recognition skill coupled with extended seductive detail passages (42\% more than base texts) might have interfered with comprehension by IP students. This interpretation has both theoretical and empirical support (Just \& Carpenter, 1992; Samuels, 2004; Stanovich, 1991). LaBerge and Samuels (1974) emphasized the role automatic word recognition skills play in reading comprehension. They argued that readers have limited working memory capacity to process information. Accordingly, when less proficient readers pay much attention to decoding words, they may not have enough attentional capacity to interrelate, combine, and integrate the separate meanings of several words and the whole passage (Samuels, 2004). This might have happened to IP readers who also had to deal with extended passages.

For overall comprehension, the results of the study showed that students who read the seductive detail versions performed worse than students who read base texts (mean difference $=$ .55). However, the marginally significant mean difference is worthy of future study.

\section{(2) Effect of Concrete Elaboration}

The results indicated that concrete elaboration did not significantly enhance student's comprehension of main ideas and overall comprehension. However, statistically significant interaction between text type and proficiency level clearly indicates that this generalization could not uniformly be applied to both HP and IP students. Analysis indicates that concrete elaboration was beneficial to main idea comprehension for HP students; conversely, it was significantly detrimental to main idea comprehension for IP students.

In further elaboration, for HP students, concrete elaboration was beneficial to their main idea comprehension. Given that concrete elaboration passages contained substantially more words than base texts (34\% more), it is important to note that HP students in the CE condition outperformed other HP students who read base texts. Equally important, for IP students, concrete elaboration 
significantly interfered with their main idea comprehension. This is a rather unexpected finding because concrete elaboration was almost as detrimental as seductive details on the main idea comprehension for IP students.

This finding is inconsistent with previous L1 concrete elaboration studies which documented unanimously positive effects of concrete elaboration on readers comprehension (Sadoski et al., 1993, 2000). Virtually no studies ever provided evidence that concrete elaboration interfered with readers comprehension. However, the findings of the study did indicate that concrete elaboration might serve as cognitive support (Sadoski et al., 1993) for L1 readers and proficient L2 readers, but not for intermediate proficiency readers in the L2 contexts.

As a further explanation for such findings, it is possible that the lack of concrete elaboration effects on IP students might have resulted from the possibility that concrete elaboration alone may not enhance comprehension of less proficient L2 readers. In addition to concretization of texts, other tactics seem necessary. For instance, in the L2 contexts, Oh (2001) used a variety of tactics such as redundancy, word definitions, and contextual clues for the sake of elaborating base texts. Although the modified text $\mathrm{Oh}$ used in her experiment contained 54\% more words than base texts, both high and low proficient L2 readers who read elaborated versions performed significantly better than their counterparts who read base texts.

Another possible interpretation of the mixed findings on concrete elaboration is that although concrete elaboration might have great potential to help L2 readers construct mental images, and eventually facilitate written text comprehension (Paivio, 1971), IP readers may not have acquired the necessary skills for effectively creating mental images which are crucial to reading comprehension. Research evidence also shows that less proficient L2 readers had trouble constructing mental pictures in their minds independently (Pransky \& Bailey, 2003). However, Pransky and Bailey found that reading comprehension of less proficient L2 readers could be promoted by continued teacher modeling and student internalization of the skill to form mental images.

\section{(3) Proficiency}

For both main idea and overall comprehension, HP students significantly outperformed IP students. This unsurprising finding indicates that general English language proficiency is a strong predictor of written text comprehension in nonnative readers. This finding is consistent with that of the previous study by Oh (2001), whose investigation showed that English language proficiency is a stronger predictor of written text comprehension. 


\section{Effect of Text Type and Proficiency on Comprehensibility and Interestingness}

The last question addresses the effects of text type and proficiency on perceived comprehension and interest of the students. The findings indicate that there were no statistically significant text type effects on self-ratings of comprehensibility and interestingness. That is, both seductive details and concrete elaboration did not significantly promote perceived comprehension and interest. The findings also indicate no statistically significant interaction between text type and proficiency. In other words, HP students provided consistently higher ratings of comprehensibility and interestingness than IP students, regardless of what type of text versions they read.

\section{(1) Comprehensibility}

Although not statistically significant, both HP and IP students who read the seductive detail passages provided the highest comprehensibility ratings. In contrast, both HP and IP students who read concrete elaboration passages gave lowest comprehensibility ratings. However, the perceived comprehension rating was discrepant with actual achieved comprehension score. For instance, while IP students who read the seductive detail passages gave highest comprehensibility rating, actual achieved comprehension scores indicate that seductive details significantly interfered with the comprehension of main ideas for IP students. As another example, HP students who read concrete elaboration passages gave the lowest comprehensibility ratings, yet their achieved comprehension score was the highest.

\section{(2) Interestingness}

Interestingness was not significantly enhanced with concrete elaboration and seductive details. Although the students who read the seductive detail passages gave higher ratings for interestingness than those who read the base and concrete elaboration passages, the difference was not significant. Moreover, interestingness ratings were lower when students read concrete elaboration passages than when they read base texts. In fact, concrete elaboration was evaluated as the least interesting among the three types of texts.

The results of comprehensibility and interestingness ratings are partly inconsistent with previous findings in the L1 context. Sadoski and his colleagues (1993) found that text concreteness had significant effects on both comprehensibility and interestingness: concrete sentences were rated as significantly more comprehensible and interesting. However, it should be noted that in Sadoski et 
al.'s experiment, the participants were instructed to rate not the whole passage, but each of the 40 sentences. Thus, it is not clear whether the concretized sentences actually enhanced the participants' comprehensibility and interestingness of the whole passage. In other words, concrete examples and sentences might have the potential to increase the comprehensibility of individual sentences, but might not have the same potential to increase the comprehensibility of the whole passage. Further research is needed.

A plausible explanation for the lowered interestingness in both the seductive detail and concrete elaboration passages might be the cognitive overload that students may be dealing with when reading longer passages. In fact, seductive details and concrete elaboration passages contained $42 \%$ and 34\% more words than did base texts. Although base, seductive details, and concrete elaboration passages were matched for readability, the redundant information in seductive details and concrete elaboration versions might have prevented IP students from forming a coherent mental representation of longer texts, which might have reduced their perceived interest.

\section{Implications and Limitations}

\section{Implications}

Although the present study is an initial effort to identify the effects of seductive details and concrete elaboration on written text comprehension and interest in the L2 contexts, the findings from the present study have practical significance for text designers and EFL English teachers. Especially in light of the ever increasing importance of level-differentiated reading instruction to meet the needs of diverse EFL readers, the results propose models for text construction, and also for comprehension instruction.

For text constructors, I recommend that they develop level-differentiated reading materials for different levels of language proficiency. This is crucial considering the fact that English textbooks are not sensitive to the proficiency levels of students. That is, they rarely care about different proficiency levels of students. Regardless of their English proficiency, students encounter the same textbooks during classroom instruction. Accordingly, for textbooks to facilitate readers' comprehension of main ideas, I specifically recommend that (a) for high proficiency level readers, text constructors enhance concreteness by adding additional examples and concrete language, and 
that (b) for intermediate proficiency level readers, text constructors do not augment seductive details and concrete segments. Unfortunately, no suggestions can be provided for low proficiency level students at this moment due to absence of empirical evidence.

The generalizations made in this study should not be taken to mean that the findings should be applied mechanically and without caution. More specifically, my suggestion does not mean that seductive details should be eliminated from all educational materials. In reality, this may not be possible, nor desirable. L2 high school readers can and must deal with seductive details. To that end, students should be encouraged by their teachers to (a) monitor their comprehension, (b) selectively allocate their attention, and (c) differentiate important ideas and interesting details. As Garner et al. (1992) argued, teachers should be advised to assist students in becoming active regulators of their own cognition.

In a related vein, enhancing concreteness is advisable for high proficiency students since concretized texts were beneficial to their comprehension. However, this finding does not necessarily mean that all texts should be rendered concrete because they need to cope with abstractions as well. Judicious application of the findings in the present study is needed.

\section{Limitations}

There are a couple of limitations that deserve discussion. First, the content and the length of the experimental texts may not reflect those of the actual texts the participants will encounter in regular classrooms and during the College Scholastic Ability Test (CSAT). The texts used in this study are about historical figures from different disciplines and contain roughly 300 words in each text. On the other hand, the actual texts that Korean high school students encounter in the classroom and during the CSAT reading comprehension test encompass a wide variety of contents: life experiences, pastimes, career issues, cultural exchange, politics, scientific and technological concepts, sports, and so on. Also, texts used in classrooms and CSAT contain approximately 600 and 80-240 words, respectively. Second, the findings of this study may not generalize to readers who differ in age, language proficiency, and mother tongue.

In conclusion, the findings do not offer a definitive conclusion as to the controversial effects of seductive details, although it is clear that seductive details did interfere with the comprehension of main ideas, especially for intermediate level students. Seductive details also had little impact on reader interest. In addition, the present study does not provide a definitive answer to the effects of concrete elaboration on EFL readers, although there was empirical evidence that supported the 
view that concrete elaboration does not necessarily increase reader comprehension and interest. The findings and suggestions are preliminary because convergent results are quite necessary. To that end, further research should be conducted in this area. This study is a first step toward that direction. 


\section{References}

Baker, L. \& Brown, A. L. (1991). Metacognitive skills and reading. In R. Barr, M, Kamil, P. Mosenthal, \& P. D. Pearson (eds.), Handbook of reading research: Volume II (pp. 353-394). White Plains, NY: Longman.

Beck, I., McKeown, M., \& Worthy, J. (1995). Giving text a voice can improve students' understanding. Reading Research Quarterly, 30(2), 220-238.

Creswell, J. W. (2003). Research design: Qualitative, quantitative and mixed methods approaches (2nd ed.). Thousand Oaks, California, USA: Sage.

Elley, W. B. (1991). Acquiring literacy in a second language: The effect of book-based programs. Language Learning, 41(3), 375-411.

Garner, R., Alexander, P.A., Gillingham, M.G., Kulikowich, J.M., \& Brown, R. (1991). Interest and learning from text. American Educational Research Journal, 28(3), 643-659.

Garner, R., Brown, R., Sanders, S., \& Menke, D. (1992). The role of interesting details in learning from text: Of boring abstract principles and "seductive details". In K. A. Renninger, S. Hidi, \& A. Krapp (eds.), The role of interest in learning and development (pp. 239-254). Hillsdale, NJ: Erlbaum.

Garner, R., Gillingham, M. G., \& White, C. S. (1989). Effects of "seductive details" on macroprocessing and microprocessing in adults and children. Cognition and Instruction, $6(1), 41-57$.

Harp, S. F. \& Mayer, R. E. (1997). The role of interest in learning from scientific text and illustrations: On the distinction between emotional interest and cognitive interest. Journal of Educational Psychology, 89(1), 92-102.

Harp, S. F. \& Mayer, R. E. (1998). How seductive details do their damage: A theory of cognitive interest in science learning. Journal of Educational Psychology, 90(3), 414-434.

Hidi, S. (1990). Interest and its contribution as a mental resource for learning. Review of Educational Research, 60(4), 549-571.

Hidi, S. \& Anderson, V. (1992). Situational interest and its impact on reading and expository writing. In K. A. Renninger, S. Hidi, \& A. Krapp (eds.), The role of interest in learning and development (pp. 215-238). Hillsdale, NJ: Lawrence Erlbaum.

Johnston, P. (1984). Prior knowledge and reading comprehension test bias. Reading Research Quarterly, 19(2), 219-239. 
Just, M. A. \& Carpenter, P. A. (1992). A capacity theory of comprehension: Individual differences in working memory. Psychological Review, 99(1), 122-149.

Kintsch, W. (1980). Semantic Memory: A tutorial. In R. S. Nickerson (ed.), Attention and performance VIII (pp. 595-620). Hillsdale, New Jersey: Erlbaum.

Klare, G. (1984). Readability. In P.D. Pearson (ed.), Handbook of reading research (pp. 681-744). New York: Longman.

Krashen, S. (1985). The Input Hypothesis: Issues and Implications. London: Longman.

Laberge, D \& Samuels, S. J. (1974). Toward a theory of automatic information Processing in Reading. Cognitive Psychology, 6(2), 293-323.

Oh, S. Y. (2001). Two types of input modifications and EFL reading comprehension: Simplification versus elaboration. TESOL Quarterly, 35(1), 69-96.

Paris, S. G. \& Myers, M. (1981). Comprehension monitoring, memory and study of strategies of good and poor readers. Journal of Reading Behavior, 13(1), 5-22.

Pransky, K. \& Bailey, F. (2003). To meet your students where they are, first you have to find them. The Reading Teacher, 56(4), 370-383.

Sadoski, M., Goetz, E.T., \& Avila, E. (1995). Concreteness effects in text recall: Dual coding or context availability? Reading Research Quarterly, 30(2), 278-288.

Sadoski, M., Goetz, E. T., \& Fritz, J. B. (1993). Impact of concreteness on comprehensibility, interest, and memory for text: Implications for dual coding theory and text design. Journal of Educational Psychology, 85(2), 291-304.

Sadoski, M., Goetz, E. T., \& Rodriguez, M. (2000). Engaging texts: Effects of concreteness on comprehensibility, interest, and recall in four text types. Journal of Educational Psychology, 92(1), 85-95.

Sadoski, M. (2001). Resolving the effects of concreteness on interest, comprehension, and learning important ideas from text. Educational Psychology Review, 13(3), 263-281.

Sadoski, M. \& Paivio, A. (2004). A dual coding theoretical model of reading. In R. B. Ruddell \& N. J. Unrau (eds.), Theoretical models and processes of reading (5th ed., pp. 1329-1362). Newark, DE: International Reading Association.

Samuels, S. J. (2004). Toward a theory of automatic information processing in reading, revisited. In R. B. Ruddell \& N. J. Unrau (eds.), Theoretical Models and Processes of Reading (5th ed., pp. 1462-1521). Newark, DE: International Reading Association.

Schraw, G. (1998). Processing and recall differences among seductive details. Journal of Educational Psychology, 90(1), 3-12. 
Schraw, G. \& Lehman, S. (2001). Situational interest: A review of the literature and directions for future research. Educational Psychology Review, 13(1), 23-52.

Schraw, G., Lehman, S., \& Hartley, K. (2002, April). Undoing the effect of seductive details: Integrating seductive details into the macropropositional textbase. Paper presented at the annual meeting of the American Educational Research Association, New Orleans, LA.

Segalowitz, S., Segalowitz, N., \& Wood, A. (1998). Assessing the development of automaticity in second language word recognition. Applied Psycholinguistics, 19(1), 53-67.

Song, S. H. (2003). The effect of interesting text on the reading comprehension of Korean College EFL students: A comparison of seductive details and interesting elaborations. Unpublished doctoral dissertation, University of Texas, Austin, TX.

Stanovich, K. E. (1991). Word recognition: Changing perspectives. In R. Barr, M. L. Kamil, P. B. Mosenthal, \& P. D. Pearson (eds.), Handbook of reading research, 2 (pp. 418-452). New York: Longman.

Tobias, S. (1994). Interest, prior knowledge,and learning. Review of Educational Research, 64(1), $37-54$.

Wade, S. E., Schraw, G., Buxton, W. M., \& Hayes, M. T. (1993). Seduction of the strategic reader: Effects of interest on strategies and recall. Reading Research Quarterly, 28(2) 93-114.

Yano, Y., Long, M. H., \& Ross, S. (1994). The effect of simplified and elaborated texts on foreign language reading comprehension. Language Learning, 44(2), 189-219.

- 논문접수 : 2006년 4월 15일/ 수정본 접수 : 2006년 5월 15 일 / 게재 승인 : 2006년 5월 24일 


\section{$\langle$ Appendix 1〉 Three Types of Reading Comprehension Passages}

\section{Base Text}

(Excerpted from Spectrum New York Test Prep Grade5. Frank Schaffer Publications, 2004, p. 14; Permission to reprint the copy obtained from the publisher)

Every day, thousands of people cross the channel of water between France and England in a variety of vehicles. An American athlete, Gertrude Caroline Ederle, however, used a different method. She became the first woman to swim across the English Channel.

Gertrude Ederle was born in New York City in 1906. At an early age she dedicated herself to the sport of swimming and enjoyed great success. Before long, she was on her way to becoming one of the most famous American swimmers of her time. When she was sixteen, Ederle broke seven records in one day at a swimming competition in New York. Two years later, in 1924, she represented the United States at the Olympic Games, winning a gold medal in the 400-meter freestyle relay.

After her Olympic victory, she looked for an even greater challenge. One of the most difficult swims is to cross the English Channel. In the past, the feat had been accomplished by only male swimmers. Most people believed that the swim was too great a challenge for a woman, but Ederle wanted to prove them wrong. She fell short on her first attempt, but in 1926 she tried again. Leaving from the coast of France, Ederle had to swim even longer than planned because of heavy seas. She went an extra fourteen miles and still managed to beat the world record by almost two hours. This accomplishment made her an instant heroine at the age of twenty.

1. What is the main idea of the passage?

A. Swimming across the dangerous English Channel is very difficult.

B. Ederle was one of the most famous American swimmers.

C. If you want to be very successful at something, you have to start at a young age.

D. Through hard work Ederle became the first woman to swim across the Channel.

E. Although she was a great swimmer, Ederle's later life was not happy.

2. According to the passage, why was Ederle considered a heroine? 
A. because she won a gold medal in the Olympic Games

B. because she was not afraid of dangers ahead of her

C. because she had stronger arms and legs than anybody else

D. because she broke seven records in one day

E. because she had done something that no other woman had ever done

3. Based on the information in the passage, what word best describes Ederle's personality?
A. careful
B. delicate
C. reckless
D. strong-minded
E. proud

\section{Seductive Details Version (Text A)}

Every day, thousands of people cross the channel of water between France and England in a variety of vehicles. An American athlete, Gertrude Caroline Ederle, however, used a different method. She became the first woman to swim across the English Channel which is often visited by sharks and poisonous jellyfish. In fact, at least 21 species of sharks appear in the English Channel. They are very dangerous and grow up to 12 meters long. In addition, some jellyfish are as big as garbage bag and they kill more people than a great White Shark.

Gertrude Ederle was born in New York City in 1906. At an early age she dedicated herself to the sport of swimming and enjoyed great success. She was only 7 years old when she first went into the water. Before long, she was on her way to becoming one of the most famous American swimmers of her time. When she was sixteen, Ederle broke seven records in one day at a swimming competition in New York. Two years later, in 1924, she represented the United States at the Olympic Games, winning a gold medal in the 400-meter freestyle relay.

After her Olympic victory, she looked for an even greater challenge. One of the most difficult swims is to cross the English Channel. In the past, the feat had been accomplished by only male swimmers. Most people believed that the swim was too great a challenge for a woman, but Ederle wanted to prove them wrong. She fell short on her first attempt, but in 1926 she tried again. Leaving from the coast of France, Ederle had to swim even longer than planned because 
of heavy seas. She went an extra fourteen miles and still managed to beat the world record by almost two hours. This accomplishment made her an instant heroine at the age of twenty.

Despite her success, she had to endure great losses over the course of this journey. She lost most of her hearing after her English Channel swim and by the 1940s she was completely deaf. As a result, she had to give her dreams of becoming a swimming teacher. Moreover, she injured her spine and had to wear casts for almost four years. She died on November 30, 2003 at the age of 97 .

\section{Concrete Elaboration Version (Text A)}

Every day, thousands of people cross the channel of water between France and England in a variety of vehicles: planes, ferries, and even trains. An American athlete, Gertrude Caroline Ederle, however, used a different method. Instead of using planes or ferries, she used her arms and legs, becoming the first woman to swim across the English Channel.

Gertrude Ederle was born in New York City in 1906. At an early age she dedicated herself to the sport of swimming and enjoyed great success. Before long, she was on her way to becoming one of the most famous American swimmers of her time. When she was sixteen, Ederle broke seven records in one day at a swimming competition in New York. Two years later, in 1924, she represented the United States at the Olympic Games, winning a gold medal in the 400-meter freestyle relay.

After her Olympic victory, she looked for an even greater challenge. One of the most difficult swims is to cross the 21-mile wide English Channel. The seas in the channel can be rough, with the temperature of the water dropping to an ice forming cold. In the past, the feat had been accomplished by only five male swimmers. Most people believed that the swim was too difficult for a woman, but Ederle wanted to prove them wrong. She didn't make it on her first attempt, but in 1926 she tried again.

Leaving from the coast of France, Ederle had to swim even longer than planned because of heavy seas. When rain began to fall, her coach begged her, "You must come out." However, she shouted back, "What for?" and did not give up swimming. She went an extra fourteen miles and still managed to beat the world record by almost two hours. This accomplishment made her an instant heroine at the age of twenty. When she returned to New York, airplanes dropped flowers and thousands of people rushed to see her. 


\section{〈Appendix 2〉 Prior Knowledge, Interestingness, and Comprehensibility Survey}

1. Gertrude Ederle에 대해서 얼마나 잘 알고 있습니까?

\begin{tabular}{|c|c|c|c|c|}
\hline 전혀 모른다 & 잘 알지 못한다 & 보통 & 조금 안다 & 아주 잘 안다 \\
\hline 1 & 2 & 3 & 4 & 5 \\
\hline
\end{tabular}

2. Gertrude Ederle에 대한 글을 읽어 본 적 있습니까?

\begin{tabular}{|c|c|c|c|c|}
\hline 한번도 없다 & 한 번 & 두 번 & 세 번 & 많이 \\
\hline 1 & 2 & 3 & 4 & 5 \\
\hline
\end{tabular}

3. 방금 읽은 글에 대해서 여러분들이 어떻게 느끼는지 알고자 합니다. 여러분들의 주관적인 판단에 따라서 답변하여 주시기 바랍니다.

* 훙미도 : 방금 읽은 글이 얼마나 훙미가 있었습니까?

\begin{tabular}{|c|c|c|c|c|}
\hline 아주 흥미 없다 & 별로 흥미 없다 & 그저 그렇다 & 조금 흥미 있다 & 아주 흥미 있다 \\
\hline 1 & 2 & 3 & 4 & 5 \\
\hline
\end{tabular}

* 이해도 : 방금 읽은 글을 얼마만큼이나 이해했다고 생각하십니까?

\begin{tabular}{|c|c|c|c|c|}
\hline $20 \%$ 미만 & $40 \%$ 정도 & $60 \%$ 정도 & $80 \%$ 정도 & $90 \%$ 이상 \\
\hline 1 & 2 & 3 & 4 & 5 \\
\hline
\end{tabular}




\section{초 록}

매우 흥미 있는 세부 내용 (seductive details) 과

텍스트의 구체화(concrete elaboration) 가 고등학교 2학년 학생들의

텍스트에 대한 이해와 흥미에 미치는 영향

최 성 묵

(버팔로 뉴욕주립대학교 박사과정)

본 연구의 두 가지 주요 목적은 다음과 같다 : (1) 매우 흥미 있는 세부 내용 (seductive details) 과 텍스트의 구체화(concrete elaboration)가 고등학교 2학년 학생들의 이해 (reading comprehension) 와 흥미 (interest)에 미치는 영향을 조사하는 것과 (2) 매우 흥미 있는 세부 내 용과 텍스트의 구체화가 효과적인 영어 교과서 디자인과 독해 교육에 지침이 될 수 있는지의 검증을 하는 것이다. 주요 발견으로는 첫째, 매우 흥미 있는 세부 내용은 영어 실력이 중위 권인 학생들의 글의 요지에 대한 이해를 저하시켰다. 둘째, 텍스트의 구체화는 영어 실력이 상위권인 학생들의 글의 요지에 대한 이해를 높여주었지만 중위권 학생들의 글의 요지에 대 한 이해력에 오히려 방해 요소로 작용했다. 세 번째로, 매우 흥미 있는 세부 내용과 텍스트 의 구체화는 현재까지의 연구 결과와는 달리 학생들의 흥미를 충분히 자극하지는 못하였다. 이와 같은 연구 결과는 교과서 집필자와 영어 교사들에게 의미하는 바가 있다. 교과서 편찬 자들은 학생들의 흥미와 이해를 증진시키기 위해 매우 흥미 있는 세부 내용과 텍스트의 구체 화를 영어 교과서에 포함시킬 때 조심스런 주의를 기울일 필요가 있다. 영어 교사들은 중간 정도의 영어 실력을 가진 학생들에게 (1) 학생들이 자기 자신의 이해도를 적극적으로 모니터 하여 요지와 매우 흥미 있는 세부 내용을 구분할 수 있도록 가르칠 필요가 있으며, 또한 (2) 영어로 된 텍스트를 읽을 때 심상(mental image) 을 효과적으로 만들어 낼 수 있도록 가르칠 필요가 있다.

주제어 : 매우 흥미 있는 세부 내용, 텍스트의 구체화, 이해, 흥미 